\title{
Time History Analysis of an Existing Structure in Accordance with Turkish \& European Standards
}

\author{
Sinem Tola, Joaquim Tinoco, José C. Matos \\ Institute for Sustainability and Innovation in Structural Engineering (ISISE), School of Engineering, \\ University of Minho, Portugal
}

\section{Elişan Filiz Piroğlu}

Institute of Earthquake Engineering and Disaster Management, Istanbul Technical University, Turkey

Contact: tola.sinem@gmail.com

\begin{abstract}
In a world of restricted natural resources, structural engineers should keep the existing buildings as long as possible since it's widely known that consumption of construction materials cause high emission of greenhouse gases. So, in terms of sustainability, a seismic performance analysis would be a critical step to decide whether it is efficient to demolish or keep the existing building. In this study, a seismic analysis comparison is performed on an existing steel structure via SAP2000 software. The seismic analysis method is Linear Time History Analysis. A comparison of results attained from dynamic analysis is obtained for an existing steel structure serving as a garage in Istanbul, Turkey. The results are demonstrated using graphics where base shear forces as well as lateral displacements obtained for two models are plotted for comparison.
\end{abstract}

Keywords: Sustainability, Time History Analysis, Eurocode 8.

\section{Introduction}

The aim of this study is the comparative evaluation of the Time History based seismic analyses according to Turkish Seismic Code 2007 [1] and Eurocode 8 [2] on an existing steel structure. For this purpose, three seismic data supplied from PEER archive [3] are scaled separately in line with the elastic design acceleration spectrums of the codes mentioned. Two structural analysis models are created, having different seismic target spectrums and the results are compared in terms of base shear forces, periods and lateral displacements parameters.

\section{Linear Time History Analysis}

\subsection{Basis of The Calculation}

The behavior of single degree of freedom systems is obtained by the solution of the equation of motion, which is a second order differential equation in the time domain, under initial conditions. The same process may be expanded for a multi-degree of freedom system like a frame system. The solution output is for example, the change of displacement with respect to time. By integrating the equation of motion of the structure in the time interval, displacement, velocity, acceleration and elastic forces could be calculated. 
This is the basis of the Time History Analysis via the acceleration records [4].

\subsection{Time History Analysis According to Turkish Seismic Code 2007}

In linear or nonlinear calculation; in the case of using three ground motions, the maximum of the results, and in the case of using at least 7 ground motions, the mean value of the results will be taken as basis for the design. In the case of using recorded or simulated ground motions, at least 3 ground motions will be produced and these will have to satisfy all three conditions for artificial ground motions.

\subsubsection{Requirements Concerning Artificial Ground Motions}

At least 3 earthquake records will be derived with the characteristics listed below and shown in Figure 1.

- The duration of the strong ground motion shall not be less than 5 times the first natural vibration period of the building and 15 seconds.

- The mean of the spectral acceleration values of the generated earthquake ground motion corresponding to the zero period will not be less than $A_{\text {og }}$ (effective ground acceleration coefficient $x$ gravitational acceleration).

- The mean of re-calculated spectral acceleration values according to each artificially produced acceleration record and $5 \%$ damping ratio, shall not be less than $90 \%$ of the elastic spectral accelerations $\left(S_{a e}(T)\right)$ for periods between $0.2 T_{1}$ and $2 T_{1}$ ( $T_{1}$ as first natural vibration period) in the earthquake direction considered. In the case of linear elastic analysis, the spectral acceleration values $\left(S_{a R}\left(T_{n}\right)\right)$ to be taken as basis of determining the reduced earthquake ground motion, will be calculated with the reduced acceleration spectrum coordinate formula.

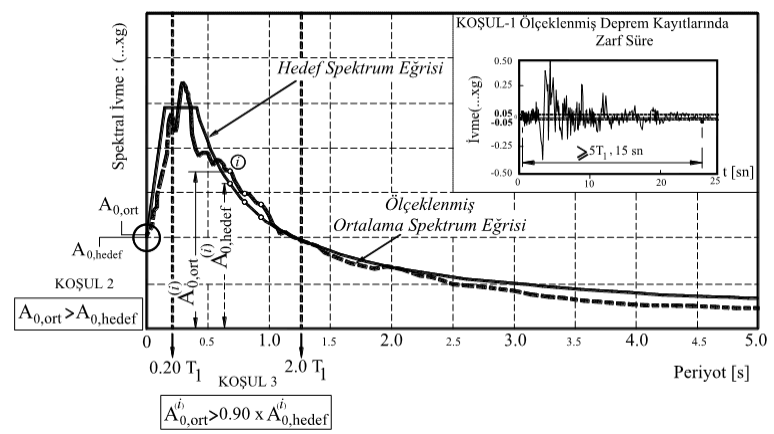

Figure 1. Requirements for the acceleration records according to Turkish Seismic Code 2007 [5].

\subsubsection{Requirements Concerning Real and Simulated Earthquake Records}

Recorded earthquakes or ground motions whose source and wave propagation properties are physically simulated could be used for earthquake calculations in time domain. Local ground conditions should also be taken into consideration when generating such ground movements.

\subsection{Time History Analysis According to Eurocode 8}

Artificial acceleration-time records could be produced to match with $5 \%$ viscose damping. The durations of the accelerograms (acceleration-time records) should be compatible with the magnitude and other relevant characteristics of the seismic event that constitutes the source of ground acceleration. The rules to be followed when using artificial acceleration records in design are:

- At least 3 accelerograms must be used.

- The mean of the acceleration values calculated from individual time intervals corresponding to the point where the period is equal to zero should not be less than the product of $a_{\mathrm{g}} . S$ in this region.

- $T_{1}$ being the first vibration period of the building in the direction of the accelerogram; at the interval of $0.2 T_{1}$ and $2 T_{1}$, any value of the mean elastic spectrum with $5 \%$ damping ratio obtained for calculation in the time definition interval, should be less than $90 \%$ of the corresponding value of the $5 \%$ damped elastic acceleration spectrum. 


\subsubsection{Utilization Recorded or Simulated Acceleration - Time Records}

Acceleration-time records created by physical simulation of the source and the distance between the region or the ones obtained from real records could be used only under the circumstances of application samples that are both sufficiently compatible with the properties of the sources to create earthquakes and the ground conditions of the region; as well as the values of these samples to be reached the value of " $a \mathrm{~g} . S$ " using a scale factor. The principles stated above for artificial acceleration-time records are also valid for the ones using simulated records.

\subsection{Ground Motion Scaling Techniques and Acceleration Records Selection Requirements}

Real earthquake acceleration records could be synchronized with the design spectrum by scaling methods of frequency and time domains.

\subsubsection{Scaling Method Applied for Single Earthquake Recording}

'Studies on the selection and scaling procedures date back to the mid-1980s' [6]. There is a difference between the amplitudes of the target design acceleration spectrum and the scaled acceleration record. In this scaling technique, the expression of the "Difference" value between amplitudes is: [5]

$\mid$ Diff. $\mid=\int_{T_{A}}^{T_{B}}\left\lfloor\alpha \cdot S_{a}^{\text {real }}(T)-S_{a}^{\text {target }}(T)\right\rfloor^{2} d T$

Where:

$S_{a}^{\text {real }}(T)$ : ordinate of the earthquake record used

$S_{a}^{\text {target }}(T)$ : ordinate of design spectrum

$\alpha$ : spectrum scale factor

$T_{\mathrm{A}}$ : lower limit of period interval which the scaling is performed

$T_{\mathrm{B}}$ : upper limit of period interval which the scaling is performed

To obtain minimum "Difference" the condition written below should be satisfied: $\frac{d \mid \text { Difference } \mid}{d \alpha}=0$

The scaling factor formula handled via this expression is:

$\alpha=\left\{\sum_{T=T_{2}}^{T=T_{1}}\left[S_{a}^{\text {real }}(T) . S_{a}^{\text {target }}(T)\right]\right\} /$

$\left\{\sum_{T=T_{2}}^{T=T_{1}}\left[S_{a}^{r e a l}(T)\right]^{2}\right\}$

In this study, the local ground class where the building is subject to the time definition interval is $\mathrm{Z3}$, group $\mathrm{C}$, and the building is located in a 2 nd degree earthquake zone. For comparison, two structural analysis models are generated for linear elastic time history analysis of the same structure. The target spectrum of the first one is the Type 1 Elastic Acceleration Spectrum (with surface wave magnitude $M_{s}>5.5$ ) specified in Eurocode 8 which is defined for regions with high seismicity. In the second structural model, the target spectrum is the design acceleration spectrum based on the earthquake having a $10 \%$ probability of exceedance in 50 years, as specified in Turkish Seismic Code 2007. The calculation steps are summarized in the following items:

- Of each acceleration record taken from the PEER archive; Characteristic features such as faulting mechanism, magnitude of the earthquake considered, distance of the recorder to the seismic source, ground conditions were determined.

- Using the method explained in Section 2.4.1 above, the actual acceleration records were shifted up or down in order to achieve the desired compatibility ratio.

- The design spectrum of the ground type was determined as the target spectrum and the $\alpha$ scaling coefficient was calculated according to this design spectrum via the formula expressed above. This process was carried out for both the Turkish Earthquake Code and Eurocode 8 (targeting the elastic design spectra specified in the relevant code).

- Spectrums belonging to real acceleration records are scaled with $\alpha_{S T}$ coefficients.

- Thus, two sets of spectra obtained according to Eurocode 8 and Turkish Seismic Code 2007, were defined as earthquake load into two structural models created in SAP2000 v.16.0.0. 
Spectral acceleration scale factor is obtained via the formula:

$\alpha_{\mathrm{i}}=A_{0} / \alpha$

$A_{0}$ : effective ground acceleration coefficient

There are some suggestions on this coefficient depending on the type of assessment. Accordingly, in linear elastic analysis, the upper limit of $\alpha_{i}$ coefficient could be accepted as 4,00. It is recommended that this coefficient should remain between $(0,50,2,00)$ in linear non-elastic analyzes and not exceed 2,00 in case of liquefaction in the soil [7].

\section{Computational Application and Calculations}

\subsection{Information of Load Bearing System}

The building is a steel construction car park located within the Bayrampaşa State Complex [8]. The building, designed according to Turkish Seismic Code 2007, consists of one basement floor, ground floor and two normal floors. The horizontal loadbearing system of the building in the $x$ direction consists of $V$-shaped concentric steel braced frames, whereas in the $y$-direction, $V$-shaped concentric steel braced moment transferring frames and moment transferring frames are combined. The vertical loads of the building are the same with its original project, while the wind loading was applied in accordance with Eurocode 1-4 [9] and the snow loading in accordance with Eurocode 1-3 [10] and TS EN 1-3.

\subsection{Analysis and Results}

The earthquake records used for Time History Analysis belong to the $1940 \mathrm{El}$ Centro earthquake. The moment magnitude of the earthquake caused by the right lateral strike slip fault was measured as 6.9. 3 real (recorded) acceleration records of this strong ground motion were imported from the database of an earthquake research center [11].

\subsubsection{Time History Analysis According to Turkish Seismic Code 2007}

The records were multiplied by a scalar number in order to match with the target spectrum with it $90 \%$ in the $0,2 \mathrm{~T}_{1}$ and $2 \mathrm{~T}_{1}$ interval, were adapted to the elastic acceleration spectrum obtained for the $2^{\text {nd }}$ earthquake zone, $\mathrm{Z3}$ ground in accordance with Turkish Seismic Code 2007. Scaled acceleration records in both $\mathrm{x}$ and $\mathrm{y}$ directions were introduced to SAP2000 as earthquake loads, and 6 load cases were obtained. The names of these loading states are TH-1X, TH-2X, TH3X, TH-1Y, TH-2Y and TH-3Y. Seismic behavior coefficients are 4 and 5 for $x$ and $y$ directions respectively. The first natural vibration periods of the building are: $\mathrm{T}_{1 \mathrm{x}}=0,363^{\mathrm{s}} \mathrm{T}_{1 \mathrm{y}}=0,369^{\mathrm{s}}$. According to Turkish Seismic Code 2007, to use the selected acceleration records in analysis; the mean of elastic spectral accelerations between the $0,2 \mathrm{~T}_{1}$ and $2 \mathrm{~T}_{1}$ interval should not be less than $90 \%$ of the $S_{a e}$ elastic spectral acceleration values defined according to the code. The intervals to be satisfying this condition are:

$x$ direction: $\left(0,2 T_{1 x}-2 T_{1 x}\right)=\left(0,0726^{s}-0,726^{s}\right)$

$y$ direction: $\left(0,2 \mathrm{~T}_{1 y}-2 \mathrm{~T}_{1 \mathrm{y}}\right)=\left(0,0738^{\mathrm{s}}-0,738^{\mathrm{s}}\right)$

In Figure 2, the curves called "RSN6_IMPVALL.I_IELC180", "RSN721_SUPER.B_B-ICCO00", "RSN832_LANDERS_ABYO00" belong to the selected recorded acceleration records, while the curve "Z3" belongs to the elastic acceleration spectrum. The mean of spectral acceleration values of 3 records with $5 \%$ damping ratio is more than $90 \%$ of the design elastic spectral acceleration values. Minimum duration of the records should be:

for $x$ direction: $\max \left[15^{s}, 5 T_{1 x}=1,815^{s}\right]=15^{s}$

for $y$ direction: $\max \left[15^{s}, 5 T_{1 x}=1,845^{s}\right]=15^{s}$

The shortest one is the $3^{\text {rd }}$ record with 50s. The compatibility of the mean of the records (black line) and the target spectrum is demonstrated in Figure 2.

\subsubsection{Time History Analysis According to Eurocode 8}

The soil type is $C$ and the corresponding soil factor $S$ parameter's value is 1,15 . The corner periods of the Type 1 elastic spectrum of this soil are $T_{B}=0,2^{\mathrm{s}}$; $T_{C}=0,6^{\mathrm{s}}$. For $5 \%$ damping ratio, damping correction factor is $\eta=1,00$. Effective ground acceleration coefficient is 0,30 for the $2^{\text {nd }}$ degree earthquake zone; The $a_{\mathrm{g}}$ value (design ground acceleration) is obtained by multiplying the reference peak ground acceleration with the 
importance factor $\gamma_{\mathrm{I}}$. For importance class II, the value of $\gamma_{1}$ importance factor is 1.00 . The behaviour coefficient in the $x$ direction is 2 and 4 for the $y$ direction. Since the corner periods of the constant acceleration range corresponding to the ground type are very close to each other, the actual acceleration records used for Turkish Seismic Code 2007 and the ones on the second model prepared according to Eurocode 8 were chosen the same. The target spectra and the scaling coefficients are different in these two models. The compatibility of the mean value of the records (black line) and the target spectrum is demonstrated in Figure 3 . In the Eurocode based model, the earthquake load names are called: TH-1X-EC, TH-2X-EC, TH3X-EC, TH-1Y-EC, TH-2Y-EC and TH-3Y-EC.

\subsubsection{Story Drift Limits}

There are limitations specified in both codes in order to limit the displacement of the building when exposed to earthquake. In terms of Turkish Code, to obtain effective story drift, the expression of " $\delta_{i}=$ R. $\Delta_{i}$ " was applied and the limit was " $\delta_{i} \leq$ 0,02 . $h_{i}$ ". According to Eurocode 8, Effective story drifts were obtained with $d_{s}=q . d_{e}$ and " $d_{\text {ri. }} v \leq$ 0,01 . $h_{i}$ " limit was considered. For structures with category number $\mathrm{II}$, the recommended value for $\mathrm{v}$ coefficient is 0,50 . Therefore, the limit value is " $d_{r i}$ $\leq 0,02$. $h_{i}$ ", similar to that specified in Turkish Seismic Code 2007.

\subsubsection{Comparison of Base Shear Forces}

The base shear forces obtained from the analysis results are demonstrated graphically in Figure 4 (for $x$ direction) and in Figure 5 (for $y$ direction). Table 1 and Table 2 show the base shear forces numerically for $z$ and Table 3 and 4 for $y$ direction respectively.

\subsubsection{Comparison of Lateral Displacements}

The maximum displacements of the floors during the acceleration records are compared in this section. In Figure 6 , displacements in the $+x$ direction are shown comparatively. Displacements in the graph are effective relative drifts in $-x$ direction. Similar comparisons could be followed in Figure 7 for $-x$ direction, Figure 8 for $+y$ direction and Figure 9 for $-y$ direction.

\section{Conclusions}

i) The first factor creates the difference between the two analyzes is different target spectras. Elastic acceleration spectrums obtained according to the ground properties are very close to each other in terms of plateau regions; according to Eurocode 8, this range is $\left[0,20^{\mathrm{s}}, 0,60^{\mathrm{s}}\right]$ for Type 1 spectrum whereas it is $\left[0,15^{\mathrm{s}}, 0,60^{\mathrm{s}}\right]$ according to Turkish Seismic Code 2007. The structure's first natural vibration period is in between the plateau regions for both codes. The second factor of disparity is that the ordinates of the elastic acceleration spectrums to be different. While the maximum spectral acceleration value according to Eurocode 8 is 0,8625 , this value is 0,75 for Turkish Code.

ii) The ductility level of the structure is medium. The structural behavior coefficient in y direction, where lateral load bearing system consists of braced moment frames, is 5 for Turkish Seismic Code 2007; while it is 4 according to Eurocode 8. Where the seismic effects are resisted via steel braces, the structural behavior coefficient in the $x$ direction is 4 for Turkish Seismic Code and 2 for Eurocode 8 because the braces are in "V" form. The effect of the structural behavior coefficients could also be followed by base shears. Such that; while the base shear forces in the $y$ direction are very close to each other, the value obtained according to the Eurocode 8 in the $x$ direction is approximately 2 times the value determined to the Turkish Seismic Code 2007. The reason shear forces in $x$ direction under 3 records for Turkish Seismic Code 2007 are 5\% higher than Eurocode 8 is that the disparity of modal mass definitions.

iii) Horizontal displacements result parallel and there is no limit 
exceedance for both codes. The effective story drift curves are in concave forms due to their initial conditions. Since there is a soft story irregularity between the basement floor and the ground floor.

iv) For both codes, RSN6_IMPVALL.I_IELC180 acceleration record generates the most unfavorable results in both directions. Base shears of this record are less than for equivalent force method according to Eurocode in both directions. Whereas equivalent force method as per Turkish Seismic Code 2007, base shears of this record are less than the ones in moment resisting direction but $25 \%$ more in the braced direction.

v) Time history method based on real acceleration records for soils with bad conditions, may result more unfavorable results than the equivalent earthquake load method according to the Turkish Seismic Code 2007. This study and many others showed the need of the improvement of Turkish Code and a new one in 2018 is released with more detailed features as seismicity map, behavior factors, building classifications etc. This study may be repeated according to the new code and developments could be seen.

\section{References}

[1] Ministry of Environment and Urbanization. Specification for Structures to Be Built in Disaster Areas. Ankara; 2007.

[2] British Standards Institution. BS EN 19981:2004. Eurocode 8. Design of Structures for Earthquake Resistance - Part 1: General Rules Seismic Actions and Rules for Buildings. London: BSI; 2004.

[3] Pacific Earthquake Research Center (PEER). Strong Ground Motion Database, Available from: https://ngawest2.berkeley.edu/ [Accessed 10th December 2014].
[4] Celep Z. Yapı Dinamiği. 4th ed. Istanbul: Beta Publish; 2011.

[5] Durgun Y. \& others, Dış Merkez Çaprazıı Bir Çelik Perdenin Deprem Performansının Doğrusal Olmayan Dinamik Hesap Yöntemi ile Değerlendirilmesi. Engineering Journal of Pamukkale University. 2013; 19(6): 266-274. Available from: https://jag.journalagent.com/pajes/pdfs/PA JES $196266 \quad 274 . p d f[A c c e s s e d$ 17th January 2021].

[6] Ay B. E. and Akkar S., A Procedure on Ground Motion Selection and Scaling for Nonlinear Response of Simple Structural Systems. Wiley Online Library, 2012. Available from: http://users.metu.edu.tr/ozer/documents/ publications/J2.pdf[Accessed 17th January 2021].

[7] Fahjan Y. M., Türkiye Deprem Yönetmeliği (DBYBHY, 2007) Tasarım İvme Spektrumuna Uygun Gerçek Deprem Kayıtlarının Seçilmesi Ve Ölçeklenmesi. Turkey Chamber of Civil Engineers Technical Journal. 2008; Writing 292: 4423-4444. Available form: https://dergipark.org.tr/en/download/articl e-file/136649 [Accessed 17th January 2021].

[8] Yazan T., Bayrampaşa Grocery Store Multi Story Garage Structural Steel Calculation Report, Orion Engineering, 2012.

[9] British Standards Institution. BS EN 1991-14:2005. Eurocode 1. Actions on Structures Part 1-4: General Actions-Wind Actions. London: BSI; 2005.

[10] British Standards Institution. BS EN 1991-13:2003. Eurocode 1. Actions on Structures Part 1-3: General Actions-Snow Loads. London: BSI; 2003.

[11] SCEDC (2013): Southern California Earthquake Centre, Imperial Valley Earthquake, Available from: https://scedc.caltech.edu/earthquake/impe rial1940.html [Caltech.Dataset. doi:10.7909/C3WD3xH1]. 


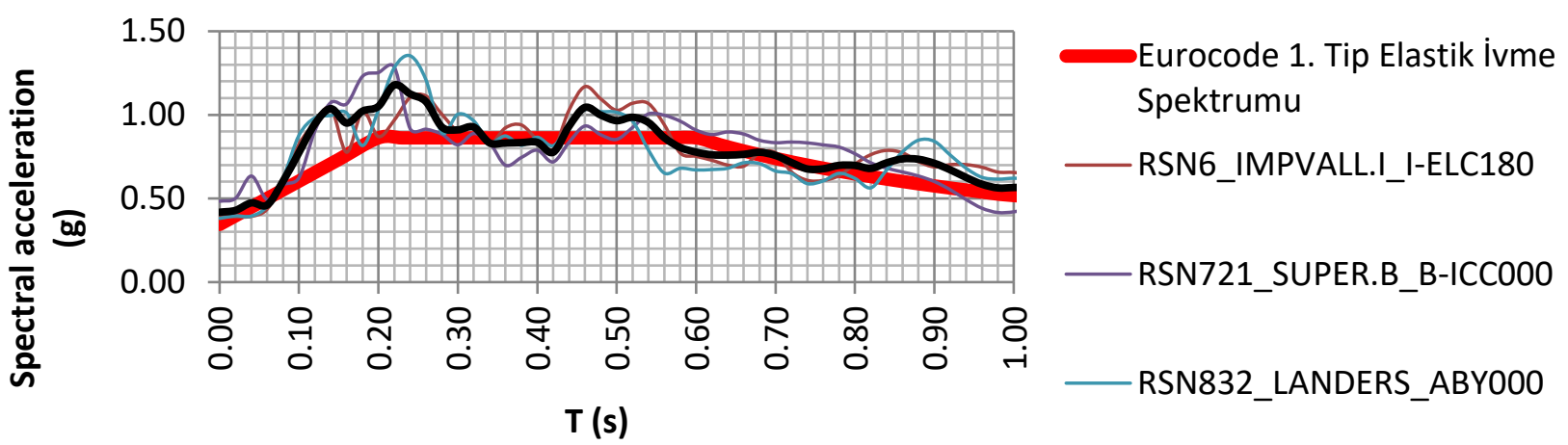

Figure 2. Compatibility of the real accelerograms and the elastic acceleration spectrum of Turkish Seismic Code 2007.

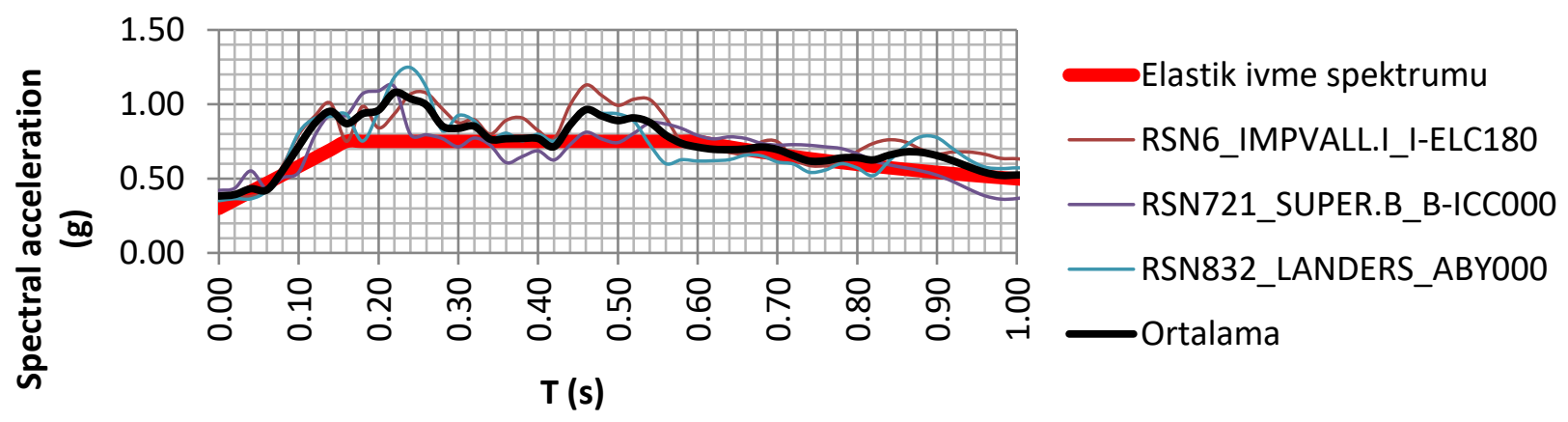

Figure 3. Compatibility of the scaled accelerograms and Type 1 elastic acceleration spectra of Eurocode 8
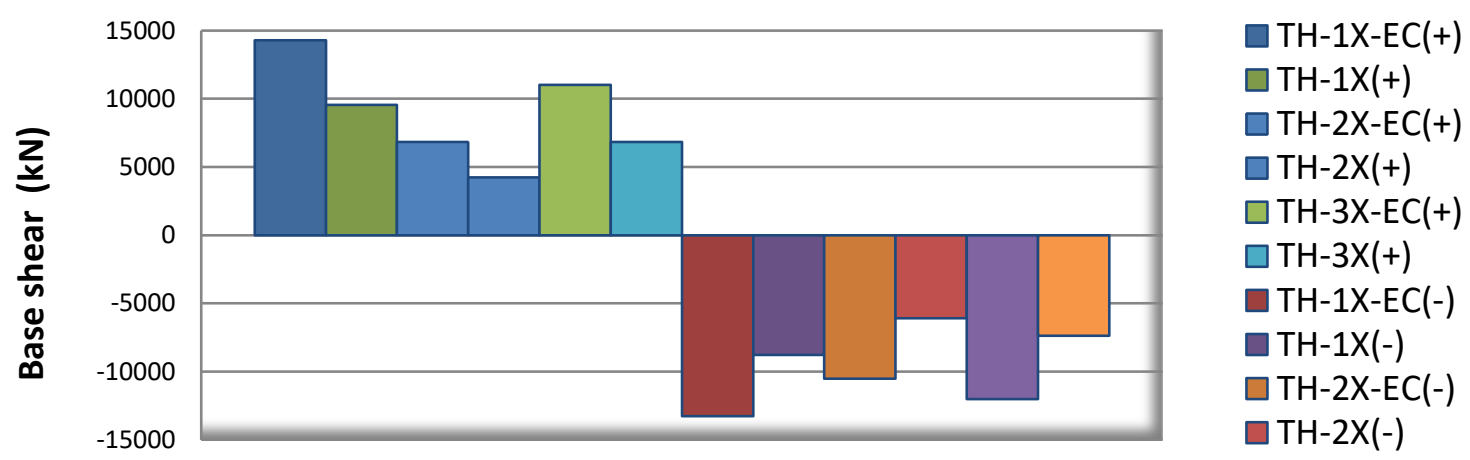

Figure 4. Graphical demonstration of base shear forces in y direction

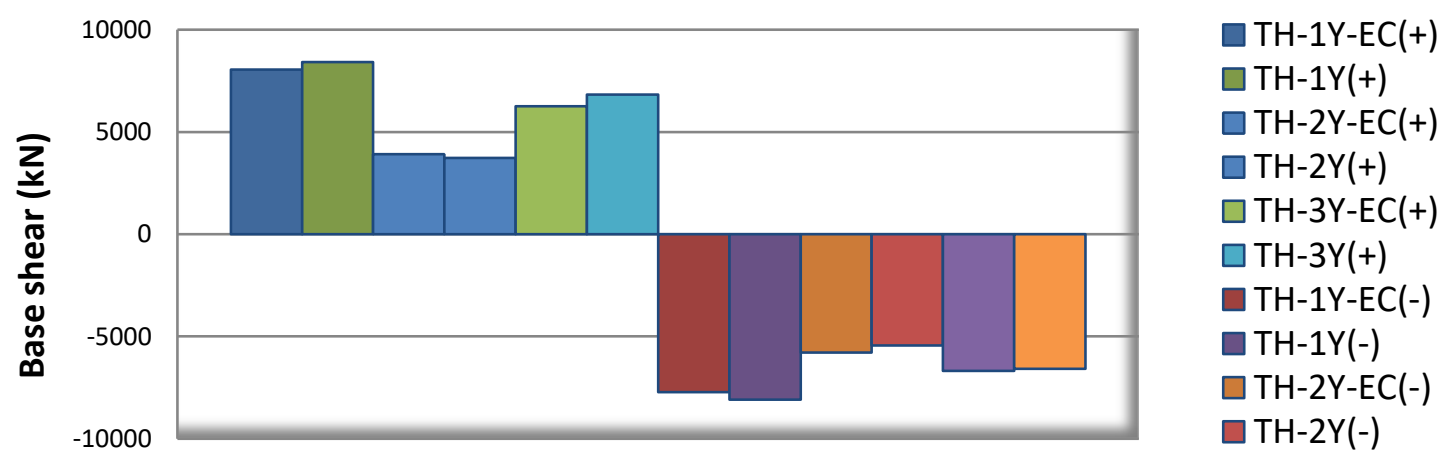

Figure 5. Graphical demonstration of base shear forces in $x$ direction. 
Table 1. X direction base shears of Turkish Seismic Code 2007 model.

\begin{tabular}{|c|c|c|c|c|}
\hline $\begin{array}{l}\text { Earthquake } \\
\text { record name }\end{array}$ & $\begin{array}{l}\text { Quake } \\
\text { Dir. }\end{array}$ & $\begin{array}{l}\text { Turkish Code } \\
\text { load case name }\end{array}$ & $V_{t}(k N)$ & $\begin{array}{l}\text { Equivalent earthquake } \\
\text { load method: } \mathrm{Vt}(\mathrm{kN})\end{array}$ \\
\hline \multirow{2}{*}{$\begin{array}{l}\text { RSN6_IMPVALL.I_I- } \\
\text { ELC180 }\end{array}$} & +x dir. & TH-1X & 9557,54 & \multirow{6}{*}{$-7118,11$} \\
\hline & $-\mathrm{x}$ dir. & TH-1X & $-8777,91$ & \\
\hline \multirow{2}{*}{$\begin{array}{l}\text { RSN721_SUPER.B_B- } \\
\text { ICC000 }\end{array}$} & +x dir. & TH-2X & 4224,79 & \\
\hline & $-x$ dir. & TH-2X & $-6082,61$ & \\
\hline \multirow{2}{*}{$\begin{array}{l}\text { RSN832_LANDERS_AB } \\
\text { Y000 }\end{array}$} & +x dir. & TH-3X & 6835,01 & \\
\hline & $-x$ dir. & TH-3X & $-7363,41$ & \\
\hline
\end{tabular}

Table 2. x direction base shears of Eurocode 8 model.

\begin{tabular}{|c|c|c|c|c|}
\hline $\begin{array}{l}\text { Earthquake } \\
\text { record name }\end{array}$ & $\begin{array}{l}\text { Quake } \\
\text { Dir. }\end{array}$ & $\begin{array}{l}\text { Eurocode } \\
\text { Load case name }\end{array}$ & $F_{\mathrm{b}}(\mathrm{kN})$ & $\begin{array}{l}\text { Equivalent } \\
\text { earthquake } \\
\text { load method: } F_{b}(k N)\end{array}$ \\
\hline \multirow{2}{*}{$\begin{array}{l}\text { RSN6_IMPVALL.I_I- } \\
\text { ELC180 }\end{array}$} & $+x$ dir. & TH-1X-EC & 14295,95 & \multirow{6}{*}{$-16843,13$} \\
\hline & $-\mathrm{x}$ dir. & TH-1X-EC & $-13264,43$ & \\
\hline \multirow{2}{*}{$\begin{array}{l}\text { RSN721_SUPER.B_B- } \\
\text { ICC000 }\end{array}$} & $+x$ dir. & TH-2X-EC & 6848,65 & \\
\hline & $-x$ dir. & TH-2X-EC & $-10515,12$ & \\
\hline \multirow{2}{*}{$\begin{array}{l}\text { RSN832_LANDERS_A } \\
\text { BY000 }\end{array}$} & $+\mathrm{x}$ dir. & TH-3X-EC & \begin{tabular}{|l|}
11009,02 \\
\end{tabular} & \\
\hline & $-x$ dir. & TH-3X-EC & $-12020,32$ & \\
\hline
\end{tabular}

Table 3. y direction base shears of Turkish Seismic Code 2007 model.

\begin{tabular}{|l|l|l|l|l|}
\hline $\begin{array}{l}\text { Earthquake } \\
\text { record name }\end{array}$ & $\begin{array}{l}\text { Quake } \\
\text { Dir. }\end{array}$ & $\begin{array}{l}\text { Turkish Code } \\
\text { load case name }\end{array}$ & $V_{t}(\mathrm{kN})$ & $\begin{array}{l}\text { Equivalent } \\
\text { earthquake } \\
\text { load method: Vt (kN) }\end{array}$ \\
\hline \hline \multirow{2}{*}{$\begin{array}{l}\text { RSN6_IMPVALL.I_I- } \\
\text { ELC180 }\end{array}$} & $+\mathrm{y}$ dir. & TH-1Y & 8416,01 \\
\cline { 2 - 4 } $\begin{array}{l}\text { RSN721_SUPER.B_B- } \\
\text { ICC000 }\end{array}$ & $+\mathrm{y}$ dir. & TH-1Y & $-8084,15$ \\
\cline { 2 - 4 } $\begin{array}{l}\text { RSN832_LANDERS_A } \\
\text { BY000 }\end{array}$ & $-\mathrm{y}$ dir. & TH-2Y & 3724,31 \\
\cline { 2 - 5 } & $-\mathrm{y}$ dir. & TH-3Y & $-5442,38$ \\
\end{tabular}

Table 4. y direction base shears of Eurocode 8 model.

\begin{tabular}{|c|c|c|c|c|}
\hline $\begin{array}{l}\text { Earthquake } \\
\text { record name }\end{array}$ & $\begin{array}{l}\text { Quake } \\
\text { Dir. }\end{array}$ & $\begin{array}{l}\text { Eurocode } \\
\text { load case name }\end{array}$ & $F_{\mathrm{b}}(\mathrm{kN})$ & $\begin{array}{l}\text { Equivalent } \\
\text { earthquake } \\
\text { load method: } F_{b}(\mathrm{kN})\end{array}$ \\
\hline \multirow{2}{*}{$\begin{array}{l}\text { RSN6_IMPVALL.I_I- } \\
\text { ELC180 }\end{array}$} & +y dir. & TH-1Y-EC & 8051,21 & \multirow{6}{*}{$-8787,72$} \\
\hline & -y dir. & TH-1Y-EC & $-7713,91$ & \\
\hline \multirow{2}{*}{$\begin{array}{l}\text { RSN721_SUPER.B_B- } \\
\text { ICC000 }\end{array}$} & ty dir. & TH-2Y-EC & 3905,62 & \\
\hline & -y dir. & TH-2Y-EC & $-5784,75$ & \\
\hline \multirow{2}{*}{$\begin{array}{l}\text { RSN832_LANDERS_A } \\
\text { BY000 }\end{array}$} & ty dir. & TH-3Y-EC & 6260,21 & \\
\hline & -y dir. & TH-3Y-EC & $-6692,01$ & \\
\hline
\end{tabular}




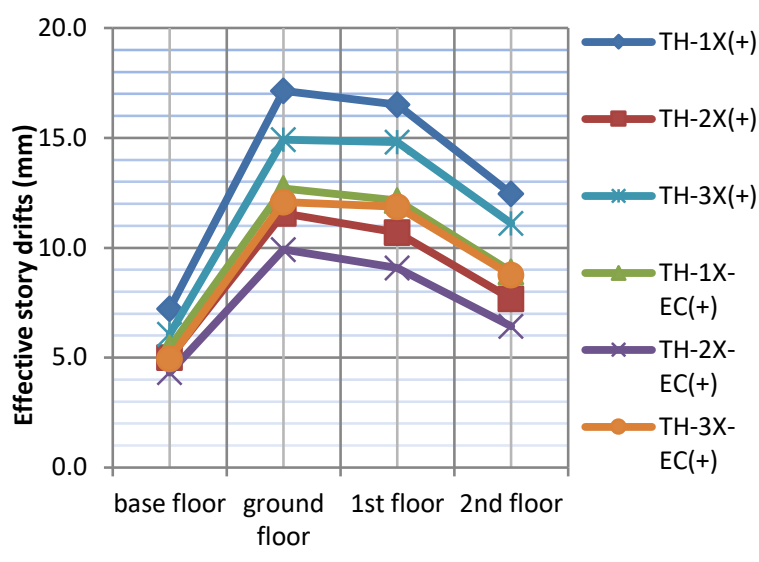

Figure 6. Effective story drifts in $+x$ direction.

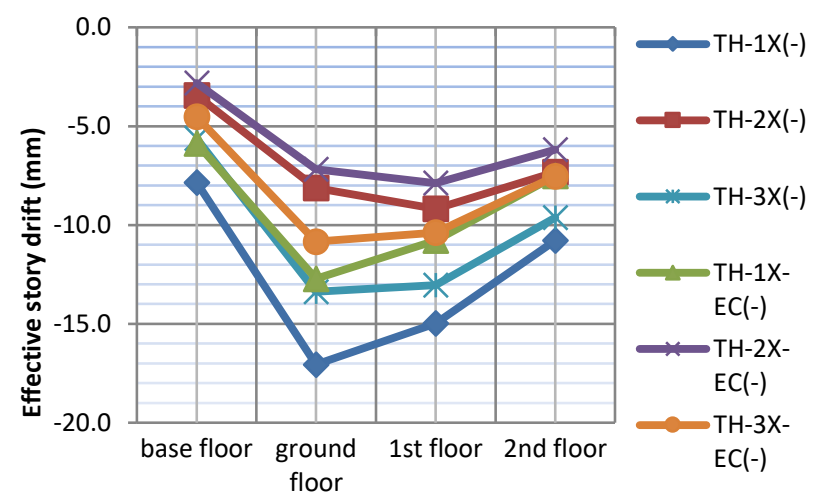

Figure 7. Effective story drifts in -x direction.

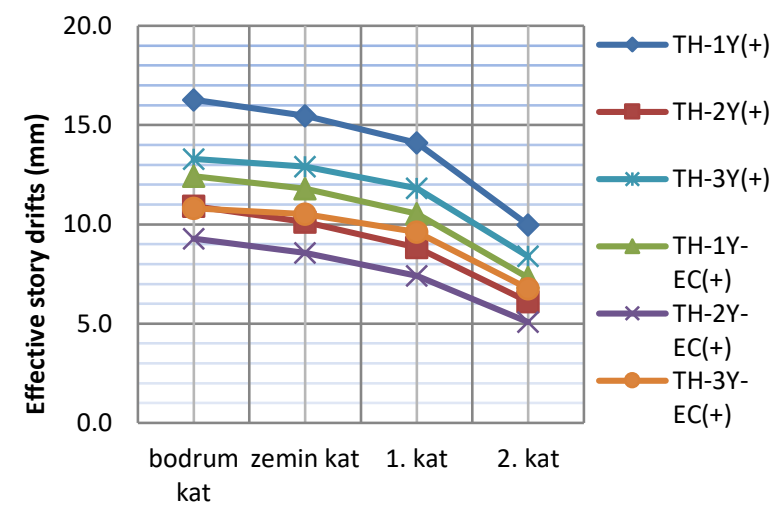

Figure 8. Effective story drifts in $+y$ direction.

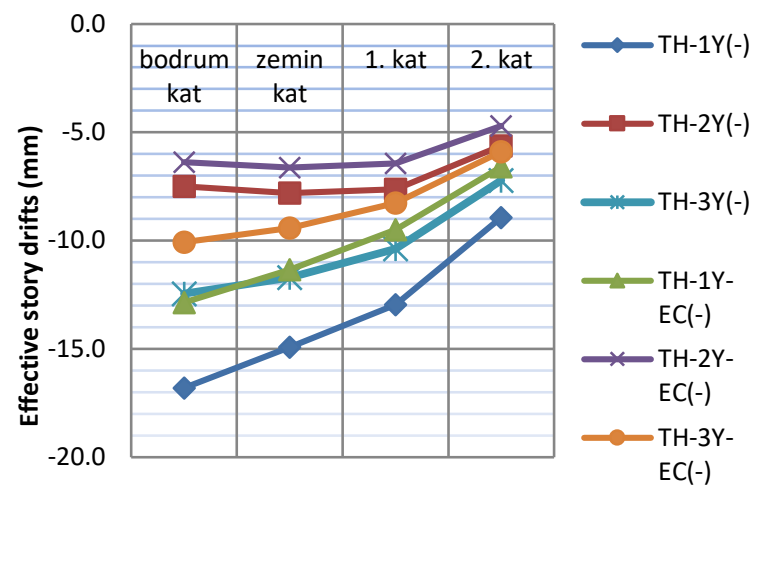

Figure9. Effective story drifts in -y direction. 